\title{
Youth, health and hope
}

\author{
Vinya S Ariyaratne \\ Sarvodaya Institute of Higher Learning, Bandaragama, Sri Lanka \\ Correspondence: vinya.ariyaratne@gmail.com \\ https://orcid.org/0000-0003-4915-8960
}

DOI: https://doi.org/10.4038/jccpsl.v25i3.8224

Received on: 1 Sep 2019

Accepted on: 4 Sep 2019

Youth are considered the most dynamic force in a country's development and future. Unfortunately, youth in Sri Lanka have received greater attention worldwide mainly due to their participation in three violent insurrections; two insurgencies involving the Sinhala youth in the South in 1971 and 1989, and the Tamil youth in North and East during 1983-2009.

Although based on the conventional indices, social wellbeing of the population in general has improved over the years; the youth in Sri Lanka have faced formidable challenges in many fronts. Issues faced by the present generation of youth in Sri Lanka include; access to higher education, employment, health, postwar reconciliation and social integration, and civic engagement and political participation. At the same time, there are opportunities that have opened up for youth with the advancement of information and communication technology (ICT) and in other areas.

We are at a critical point in the country's history with the end of a violent conflict 10 years ago. The demographic transition with youth is at the centre of change, hence an opportune moment to reflect on the past, assess the present and plan for the future.

There is no universally accepted standard definition of youth in terms of the age bracket. In Sri Lanka, the National Youth Policy (2014) defines youth as young people belonging to the age group 15-29 years. Following this definition, according to the 2012 Census, the youth population is estimated at 4.4 million and comprises nearly a quarter $(23.2 \%)$ of the total population. The WHO defines individuals in the 1019-year age group as 'adolescents' and 'youth' as the 15-24-year age group, while 'young people' covers the age range 10-24 years.

\section{Youth and health}

A healthy youth population is an essential prerequisite for the country's future. At the same time, youth themselves play a vital role in maintaining health and wellbeing in their local community.

A comprehensive national survey carried out by the Family Health Bureau (FHB) of Ministry of Health revealed some important findings related to physical and psychological health, education and productive engagement, lifestyles, knowledge and skills on sexual and reproductive health (SRH), use of information and media, diet and nutrition, substance abuse, violence, sexual behaviour and contraceptive use. The survey findings reveal the gravity and extend of health-related issues confronted by the present generation of youth in Sri Lanka and highlighted the urgency of addressing them. The survey revealed the absence of pathways on opportunities for economic advancement and selfreliance, family as the most important unit which influence them and their behaviour. However, at the same time, the economic security within their family environment was inadequate. Furthermore, the survey observed that risk facing behaviour and negative attitudes were higher amongst youth who did not have a caring family environment. 
It is encouraging to note that the $\mathrm{FHB}$ recognizing the need for an integrated set of policies, strategies and programs that address the needs of the adolescents and youth in a holistic manner, prepared the National Strategic Plan on Adolescent and Youth Health (20182025). It is our fervent hope that the multi-sectoral interventions that are proposed in the plan will get fully implemented in a coordinated manner.

\section{Political participation and reconciliation}

Given the history of youth involvement in armed conflicts, one of the most important priorities for youth in Sri Lanka is their active participation in governance and reconciliation. A recent study conducted by the Sarvodaya Institute of Higher Learning (SIHL) in partnership with the British Council and the University of Peradeniya (March 2019) explored the attitudes and aspirations of post war youth. This study illuminates post-war youth aspirations and attitudes providing fresh insights to different dynamics at the grassroots level. Some attitudes and aspirations have remained the same; but some reflect greater change and force us to understand youth affairs in a new light.

According to the study, $71 \%$ of Sri Lankan youth believe and associate their immediate identity as 'Sri Lankan', while $21 \%$ view their identity as members of the 'humankind' transcending the national identity. The remaining percentage reflected geographical identification, creed, caste as well as race to be important when they refer to their own identity. Another key finding relates to how Malayah Tamil Youth (upcountry/estate) aspires to be identifying them as 'Sri Lankan Tamil'. Overall, it reflects that mechanisms to identify all citizens as 'Sri Lankans' have had a positive impact.

The study reflects that Sri Lankan youth views education as a ladder to achieve good quality of life, decent employment opportunities and social security. At the same time, the youth view the education system as not catering to the demands of the modern age or the job market. They aspire to learn beyond their classrooms and curricula. They have voiced out for the need to review and revise the teaching methods, curriculum development especially on soft skills education. The study reflects that Sri Lankan youth finds education to be an important element influencing their personal and community life. It also sheds light that youth view the importance of cohesion and values education with high regard. They view such initiatives should begin with the delivery of primary education.

Youth view state sector employment as unsatisfying due to the political influences, nepotism, patronage and canvassing they have to meddle in securing state sector employment. They also see recruitment procedures as discriminatory in the state sector. Northern and Eastern youth have particularly voiced the need for decent employment opportunities both in the state sector and private sector within their particular provinces. They view the economy as stagnating and sectors, such as entrepreneurship initiatives largely lacking. They wished for better-informed opportunities to pursue entrepreneurial avenues. Malayaha Tamil youth particularly expressed their dissatisfaction regards to wages and the high cost of living they have to battle on a daily basis.

Around $87 \%$ of the participants have not been involved with any violent incidents in the recent past. In terms of experiencing violence, the majority was from the North and East. Interestingly, there was no significant gender difference in reporting the exposure to violence. Gang violence was noted as a major cause of violence in the North and East as well as in other parts of the country. Young people particularly from the North fear going out of their own neighbourhoods and districts and the report sheds light on diverse concerns they have.

Politics and agency have been a major theme of the research and majority of youth $(63 \%)$ viewed democracy as the best political system for the country. They believe that a democratic system would bring about a strong economy, welfare, preference for human rights, diversity and also helping to curb corruption. The second best they thought to be was social democracy (15\%). Although they viewed democracy to be the best, only $15 \%$ of the participants thought that democracy has brought personal or family level benefits to them. Majority was uncertain whether democracy has been good for them. This reflects the harsh realities they live in and the aspirations of achieving the true benefits of democracy in its real sense. In terms of political representation, youth have viewed voting as important. A clear majority (90\%) views that they have a responsibility as citizens to vote. About $47 \%$ viewed that they are interested in political events and issues, while $32 \%$ viewed that they are 
neutral about political issues. They view corruption as the key factor which hinders true development of the country. They expressed that they would prefer parties with attractive youth-oriented policies and benefits.

In terms of reconciliation, the findings reveal that majority of young people had not heard about official government initiatives such as the LLRC, ONUR, OMP or the National Policy in Reconciliation. At an alarming rate, young people did not view these mechanisms as delivering their respective mandates and that they fail to address the true needs for social cohesion at the grassroots. However, the majority feels a sense of safety after the war and $82 \%$ believes that there is improved personal freedom. Youth at an overall level aspired to live in a peaceful country which brings them personal as well as communal benefits.

\section{Conclusion}

In conclusion, Sri Lanka's youth need to be given greater freedom, opportunity and support to be equal players in defining the future of the nation. Their needs and aspirations should be met through an integrated and holistic approach. There is great hope. Leadership development of youth at all levels is an important and critical factor in this process.

\section{References}

UNDP Sri Lanka. Sri Lanka National Human Development Report 2014. Youth and development: towards a more inclusive future. Colombo: United Nations Development Program Sri Lanka, 2014.

Ministry of Youth Affairs \& Skills Development. National Youth Policy Sri Lanka. Available from: https://www.youthpolicy.org/national/Sri_Lanka_ 2014_National_Youth_Policy.pdf.

DCS. Census of Population and Housing 2012. Colombo: Department of Census \& Statistics, Ministry of Policy Planning and Economic Affairs, 2012.

FHB. National Youth Health Survey 2012/2013 Sri Lanka. Colombo: Family Health Bureau, 2013.

FHB. National Strategic Plan on Adolescent and Youth Health 2018-2025. Colombo: Family Health Bureau, 2019.

British Council. Next Generation Sri Lanka. 2019. Colombo: British Council \& Sarvodaya Institute of Higher Learning, 2019. 